\title{
Profile of Polycyclic Aromatic Hydrocarbons in Soil Environment around Selected Auto-Technicians' Workshop in ObioAkpor, Rivers State Nigeria
}

\author{
Utibe Ita Daniel' ${ }^{1}$ Isaac Azubuike Utuh ${ }^{2}$, Eucharia Oluchi Nwaichi ${ }^{3 *}$ \\ ${ }^{1}$ Department of Animal and Environmental Biology, University of Port Harcourt, Port Harcourt, Nigeria \\ ${ }^{2}$ Centre for Occupational Health, Safety and Environment (COHSE), University of Port Harcourt, Port Harcourt, Nigeria \\ ${ }^{3}$ Department of Biochemistry, University of Port Harcourt, Port Harcourt, Nigeria \\ Email: *nodullm@yahoo.com
}

How to cite this paper: Daniel, U.I., Utuh, I.A. and Nwaichi, E.O. (2020) Profile of Polycyclic Aromatic Hydrocarbons in Soil Environment around Selected Auto-Technicians' Workshop in ObioAkpor, Rivers State Nigeria. Journal of Environmental Protection, 11, 399-407.

https://doi.org/10.4236/jep.2020.115023

Received: December 30, 2019

Accepted: May 9, 2020

Published: May 12, 2020

Copyright $\odot 2020$ by author(s) and Scientific Research Publishing Inc. This work is licensed under the Creative Commons Attribution International License (CC BY 4.0).

http://creativecommons.org/licenses/by/4.0/

(c) (i) Open Access

\begin{abstract}
A study on the storage and disposal practices of spent oil from Automobile workshops in ObioAkpor Local Government Area of Rivers state was conducted to determine the levels of polycyclic aromatic hydrocarbons (PAHs) in soil samples. Questionnaire was administered and a total of 150 autotechnicians were sampled. Taro Yamani formula was used to determine the sample size. Soil samples were collected at depths of $0-15 \mathrm{~cm}$ from 8 randomly selected sites and analyzed for PAH. Control consisted of a similar soil with no history of spent oil-contamination. Results showed that autotechnicians had little or no formal education. Only $51 \%$ of respondents had secondary/technical education. $94 \%$ of the study population disposed of their generated spent oil in various types of containers before disposal. $94 \%$ disposed of their spent oil by selling. $60 \%$ of the autotechnicians were not aware that spent oil was hazardous. More so, $76 \%$ were not aware that spent oil could be recycled. Analysis of soil samples showed that mean concentration of PAH was lower than the DPR standard in all locations. Control values did not show any consistent pattern when compared with the test values in all locations. Soil contamination by PAH in the study area ranged from minor to severe. The automobile workshops pose potential sources of PAH pollution. The study recommends enactment and enforcement of legislations to control the management of spent oil.
\end{abstract}

\section{Keywords}

Auto-Technicians, Disposal Practices, Spent Oil, Soil Contamination, PAHs 


\section{Introduction}

Autotechnician's workshops, popularly called "mechanic" workshops in Nigeria, perform a very important role in the transportation industry in Nigerian economy since they provide services to vehicle and road users. Again, being a developing country, Nigeria patronizes many fairly-used vehicles, thus increasing patronage of auto-technicians on a daily basis especially by commercial motorists. Some of their activities include battery replacement, changing of oil and oil filters, general servicing, etc. As a result of these activities, they generate some wastes that include spent oil, old batteries, brake pads and linings, and tyres. All these wastes, and more, have the ability to contaminate the environment if not collected, stored, segregated and disposed of with care. Should this happen, it will cause pollution of the environment leading to serious health effects in plants and animals, including man.

Although there is no current data on the annual volume of spent oil generated in Nigeria, a large amount is generated each year in automobile workshops when engine oil is changed. There are an increasing number of motor vehicles all over the world; and this has led to the increased generation of spent oil. According to data released by the Nigeria Bureau of Statistics (NBS), Nigeria had 11.5 million vehicles as in the first quarter of 2017 [1]. A pilot study of spent oil generated in 2004 gave an estimated annual volume of 200,000,000 litres in Nigeria [2]. Spent oil can thus be described as a cocktail of toxic compounds. By its very nature of being sticky and heavy, it lingers and accumulates in the environment for long periods of time [3]. It is for this reason that legal frameworks on proper management of spent engine oils are put in place in most developed countries. This ensures that automobile workshops in these countries manage the spent oil they generate optimally.

Unfortunately, there are no such laws, regulations and standards in developing countries, such as Nigeria, to guide the activities of motor vehicle repair workshops [4]. The objectives of this study therefore, include assessing storage and disposal practices for generated spent engine oil among automobile workshops in Port Harcourt, evaluating the knowledge of health and environmental hazards of spent oil among auto-technicians and ascertaining level of polycyclic aromatic hydrocarbons around automobile workshops.

\section{Materials and Methods}

Study Area and Research Design

The study was carried out in September, 2018 in ObioAkpor Local Government Area (LGA) in Rivers state. ObioAkpor LGA is located between latitudes $4^{\circ} 45^{\prime} \mathrm{N}$ and $4^{\circ} 60^{\prime} \mathrm{N}$ and longitudes $6^{\circ} 50^{\prime} \mathrm{E}$ and $8^{\circ} 00^{\prime} \mathrm{E}$ (Figure 1 ). It is bounded by Ikwerre LGA to the north, Port Harcourt LGA to the south, Oyigbo LGA to the east, and Emohua LGA to the west. The study adopted a cross-sectional design and employed the use of a structured questionnaire and laboratory analysis of collected soil samples from selected automobile workshop environment. Table 1 
Table 1. GPS locations of the sample points.

\begin{tabular}{|c|c|c|}
\hline S/No & Sample Points & GPS Locations \\
\hline 1. & Uche Benz, Choba & Longitude $4^{\circ} 52^{\prime} 30^{\prime \prime} \mathrm{N}$ and $4^{\circ} 55^{\prime} 00^{\prime \prime} \mathrm{N}$ and Latitude $6^{\circ} 00^{\prime} 30^{\prime \prime} \mathrm{E}$ and $6^{\circ} 54^{\prime} 30^{\prime \prime} \mathrm{E}$ \\
\hline 2. & IK Japanese, Elimgbu & Longitude $6^{\circ} 37^{\prime} 39^{\prime \prime} \mathrm{N}$ and $4^{\circ} 5^{\prime} 00^{\prime \prime} \mathrm{N}$ and Latitude $5^{\circ} 00^{\prime} 30^{\prime \prime} \mathrm{E}$ and $5^{\circ} 54^{\prime} 4^{\prime \prime} \mathrm{E}$ \\
\hline 3. & Rotimi, Mgbuoshimini & Longitude $4^{\circ} 37^{\prime} 48^{\prime \prime} \mathrm{N}$ and $4^{\circ} 58^{\prime} 00^{\prime \prime} \mathrm{N}$ and Latitude $6^{\circ} 00^{\prime} 62^{\prime \prime} \mathrm{E}$ and $6^{\circ} 54^{\prime} 57^{\prime \prime} \mathrm{E}$ \\
\hline 4. & Victor, Rukpokwu & Longitude $5^{\circ} 36^{\prime} 30^{\prime \prime} \mathrm{N}$ and $4^{\circ} 55^{\prime} 00^{\prime \prime} \mathrm{N}$ and Latitude $7^{\circ} 00^{\prime} 42^{\prime \prime} \mathrm{E}$ and $6^{\circ} 24^{\prime} 47^{\prime \prime} \mathrm{E}$ \\
\hline 5. & Emenike, Rumuodara & Longitude $5^{\circ} 13^{\prime} 10^{\prime \prime} \mathrm{N}$ and $4^{\circ} 55^{\prime} 00^{\prime \prime} \mathrm{N}$ and Latitude $6^{\circ} 00^{\prime} 10^{\prime \prime} \mathrm{E}$ and $6^{\circ} 54^{\prime} 20^{\prime \prime} \mathrm{E}$ \\
\hline 6. & Ike Mobile, Rumuokwuta & Longitude $4^{\circ} 52^{\prime} 30^{\prime \prime} \mathrm{N}$ and $4^{\circ} 55^{\prime} 00^{\prime \prime} \mathrm{N}$ and Latitude $6^{\circ} 00^{\prime} 45^{\prime \prime} \mathrm{E}$ and $6^{\circ} 54^{\prime} 56^{\prime \prime} \mathrm{E}$ \\
\hline 7. & Blessed, Rumuomasi & Longitude $6^{\circ} 36^{\prime} 30^{\prime \prime} \mathrm{N}$ and $5^{\circ} 52^{\prime} 00^{\prime \prime} \mathrm{N}$ and Latitude $7^{\circ} 00^{\prime} 30^{\prime \prime} \mathrm{E}$ and $7^{\circ} 54^{\prime} 12^{\prime \prime} \mathrm{E}$ \\
\hline 8 & Jafaru, Trans Amadi & Longitude $6^{\circ} 12^{\prime} 20^{\prime \prime} \mathrm{N}$ and $4^{\circ} 55^{\prime} 00^{\prime \prime} \mathrm{N}$ and Latitude $7^{\circ} 00^{\prime} 30^{\prime \prime} \mathrm{E}$ and $7^{\circ} 24^{\prime} 60^{\prime \prime} \mathrm{E}$ \\
\hline
\end{tabular}

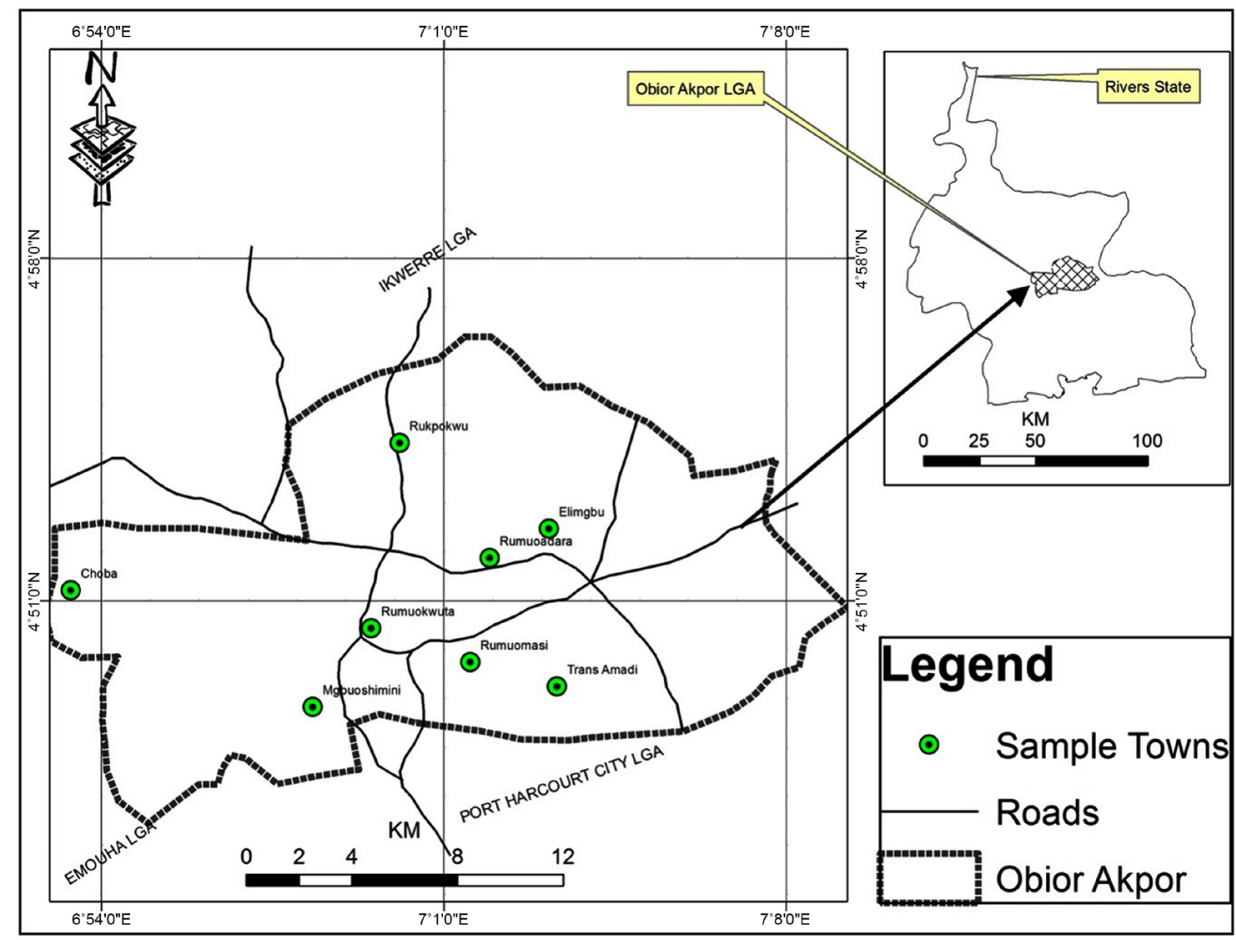

Figure 1. Map of ObioAkpor, rivers state, Nigeria showing studied communities.

shows the coordinates for the study sampling points. Questionnaire from OHS 45001 was adapted to obtain information on personal data of auto-technicians and they include age, gender, educational status, marital status; their storage practices around spent oil; their disposal practices of spent oil; and their awareness status on health and environmental hazards of spent oil.

A random selection of eight (8) automobile workshops in Obio/Akpor Local Government Area (LGA) was done and soil samples collected from them. Samples from an uncontaminated fallow lying site at the Choba campus of the University of Port Harcourt was used as control.

Population of the Study

The study population comprised of all the autotechnicians in Obio/Akpor 
LGA. Eight (8) randomly selected communities (Choba, Rukpokwu, Trans Amadi, Elimgbu, Mgbuoshimini, Rumuodara, Rumuomasi and Rumuokwuta) out of thirty two (32) communities in ObioAkpor LGA had ninety one (91) automobile workshops with a total of two hundred and forty (240) personnel working in them.

One (1) automobile workshop in each of the 8 designated communities was randomly selected for soil sampling, giving a total of 8 sample areas and three random points were sampled.

Sample and Sampling Techniques

The simple random procedure was adopted at each stage of this study in order to reduce bias and allow all the elements in the sample to have equal or zero chance of being selected. According to the National Population Commission [5], there are thirty two (32) communities that make up ObioAkpor LGA as shown in Figure 1. This was confirmed by a reconnaissance survey by the researcher. Out of the 32 communities, 8 were randomly selected using the ballot method.

A total of two hundred and forty (240) auto-technicians were identified in the sampled communities (Table 2). The Taro Yamani [6] formula was used to obtain a sample size of one hundred and fifty (150). Out of the 150 copies of the randomly administered questionnaires, only 144 were retrieved and properly filled, giving a response rate of $96 \%$. Six (6) copies were neither retrieved nor properly filled.

Obtaining the sample size using the Taro Yamani formula is as shown in equation 1:

$$
n=\frac{N}{1+N(e)^{2}}
$$

$n=$ sample size

$N=$ population size

$e=$ acceptable sampling error $=0.05$

Table 2. Number of automobile workshops in the sampled communities.

\begin{tabular}{cccc}
\hline Sampled communities & $\begin{array}{c}\text { No. of automobile } \\
\text { workshops }\end{array}$ & No. of auto-technicians & $\begin{array}{c}\text { No. of auto-technicians } \\
\text { sampled }\end{array}$ \\
\hline Choba & 12 & 27 & 17 \\
Rukpokwu & 7 & 20 & 13 \\
Trans Amadi & 13 & 28 & 18 \\
Elimgbu & 8 & 29 & 18 \\
Mgbuoshimini & 10 & 31 & 19 \\
Rumuodara & 13 & 35 & 22 \\
Rumuomasi & 13 & 39 & 19 \\
Rumuokwuta & 15 & 240 & 24 \\
Total & 91 & & 150 \\
\hline
\end{tabular}




$$
n=\frac{240}{1+240(0.05)^{2}}=150
$$

Methods of Data Collection/Instrumentation

A random selection in ObioAkpor LGA was done out of which 8 communities were selected and questionnaires were administered to the derived 150 auto-technicians. Soil samples were collected in triplicates from each of the selected sites at $0-30 \mathrm{~cm}$ soil depth both for test and control sites. Each sample was placed in a new black polythene bag, properly sealed and labelled accordingly and were immediately taken to the laboratory for analysis.

Polycyclic Aromatic Hydrocarbons (PAHs) determination in soil samples

In triplicates, two (2) grams of well-mixed soil sample were weighed into a solvent rinsed beaker and a gram of anhydrous sodium sulphate was added. A 10 $\mathrm{ml}$ of solvent-mix (1:2 of hexane and dichloromethane) was added and stirred for 15 minutes using a magnetic stirrer and the sample was poured into a round bottom flask. It was stirred and allowed to settle and then decanted into the same round bottom flask. The sample was concentrated to $2 \mathrm{ml}$. One (1) $\mathrm{ml}$ of the extract was added to the column and $10 \mathrm{ml}$ of dichloromethane was used to elute and collect for aromatic constituents. The extract was concentrated to $1 \mathrm{ml}$ and poured into a glass vial for GC run. The analysis was carried out using GC FID 5890 series II model following user's manual.

Statistical Analysis

Descriptive statistics involved the use of percentages, mean, minimum, maximum, standard deviation, etc. However, advanced statistical methods used Statistical Package for Social Sciences (SPSS) 17.0 for matrix correlation analysis (Pearson).

\section{Results}

Demographic Data

The results from demographic data with regards to gender revealed that $96 \%$ (138) of the respondents were males while only $4 \%$ (6) were females. Based on Educational qualification, 23\% (33) of the respondents had only primary education or apprenticeship. 26\% (37) had Junior Secondary level of education, and $51 \%$ (74) had up to Senior Secondary/Technical level of education. None had any tertiary level of education. Regarding storage practices, 94\% (135) of study population had some form of storage facility for storing the spent oil they generated. A 6\% (9) of mechanics had no form of storage facility. Based on disposal practice $94 \%$ (136) of selected auto-technicians sold the spent oil they generated while $2 \%$ (3) of mechanics disposed of their spent oil on the ground. The remaining $4 \%$ (5) practiced other forms of disposal practices. With regards to awareness of Hazards of Spent Oil, 60\% (87) of respondents said they had no idea that spent oil had any health or environmental hazards, while $40 \%$ (57) had some knowledge of the hazards of spent oil. Based on awareness of spent oil recycling; only $24 \%$ (35) of the auto-technicians were aware that spent oil could be 
recycled. The remaining 76\% (109) were not aware of recycling.

Mean Concentrations of PAHs (mg/kg) in Study Samples

The polycyclic aromatic hydrocarbons (PAHs) found in the soil test and control samples as well as the standard recommended by WHO are shown in Table 3. For the control, the PAHs was $231.86 \mathrm{mg} / \mathrm{kg}$ while in Choba, the PAHs level was higher and gave $404.16 \mathrm{mg} / \mathrm{kg}$. In Elimgbu, PAHs values gave $283.81 \mathrm{mg} / \mathrm{kg}$ and $227.73 \mathrm{mg} / \mathrm{kg}$ in Mgbuoshimini samples. In Rukpokwu, the PAHs value obtained was $315.26 \mathrm{mg} / \mathrm{kg}$ and $537.22 \mathrm{mg} / \mathrm{kg}$ for Rumuodara samples. For Rumuokwuta, Rumuomasi and Trans Amadi samples, the levels of PAH were $330.65,257.54$, and $214.83 \mathrm{mg} / \mathrm{kg}$ respectively. These were above the WHO set limit.

\section{Storage Practices}

In terms of storage practices, 94\% (135) of autotechnicians had some form of storage facility for storing the spent oil they generated while 6\% (9) had no form of storage facility.

Disposal Practices

A 94\% (136) of mechanics sold the spent oil they generated. $2 \%$ (3) of mechanics disposed of their spent oil on the ground. The remaining 4\% (5) practiced other forms of disposal practices as shown in Figure 2.

\section{Discussion}

The study showed that $96 \%$ (138) of the auto-technicians were males while only $4 \%$ (6) were females. The low presence of females in this trade may be attributed to the fact that it is an occupation that requires physical strength. This finding is in agreement with that of Omorowa and Agu [7] who found a male percentage of $93 \%$ in the auto-technicians population.

Many auto-technicians were not well educated since they have low socioeconomic background. This was confirmed in this study where 51\% (74) of respondents had only Senior Secondary or Technical education. Twenty six percent

Table 3. Mean concentrations of PAHs $(\mathrm{mg} / \mathrm{kg})$ in study samples.

\begin{tabular}{cc} 
Sample ID & PAH concentration \\
Control & $231.86 \pm 22.499$ \\
Choba & $404.16 \pm 69.940$ \\
Elimgbu & $283.81 \pm 22.932$ \\
Mgbuoshimini & $227.73 \pm 2.352$ \\
Rukpokwu & $315.26 \pm 28.842$ \\
Rumuodara & $537.22 \pm 2.650$ \\
Rumuokwuta & $330.65 \pm 24.289$ \\
Rumuomasi & $257.54 \pm 55.446$ \\
Trans Amadi & $214.83 \pm 14.875$ \\
WHO standard & 1.00 \\
\hline
\end{tabular}

Values (mean \pm S.E.M.), $n=3$. 


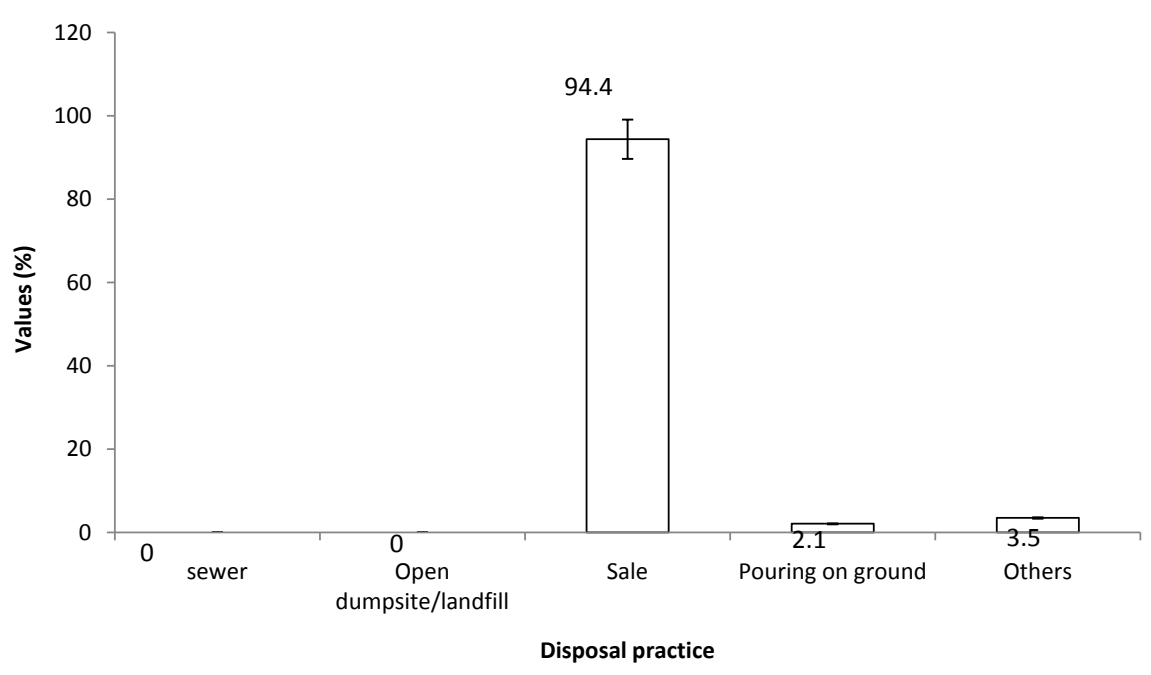

Figure 2. Disposal practices observed among respondents.

(37) had only Junior Secondary education, while 23\% (33) had either primary education or apprenticeship training. None had any tertiary education. This finding contrasted that of Akpakpavi [4] who found that 5\% of auto-technicians had tertiary education, while $74 \%$ had primary education or apprenticeship training.

On the issue of storage practices, $94 \%$ (135) of auto technicians practiced some form of storage of the spent oil generated while $6 \%$ (9) had no storage facility. This storage practice could be attributed to economic reasons as most of the auto-technicians now sell off their generated spent oil for economic gains.

The disposal practices of spent oil by respondents in this study revealed that 94\% (136) of auto mechanics sold the spent oil they generated while $2 \%$ (3) of respondents poured their generated spent oil on the ground and $4 \%$ (5) of population did not disclose their disposal methods. However, Zitte et al. [8] observed that up to $65 \%$ of auto-technicians in Port Harcourt disposed of their generated spent oil directly on land. The difference in the findings in the present study may be attributed to the current hard economic realities in the country whereby auto-technicians now preferred to sell what they hitherto disposed of indiscriminately. On this score, Nwachukwu et al. [3], Akpakpavi [4] and Zitte et al. [8] noted that there are sundry re-use practices concerning spent oil. Those who practice these re-use methods usually buy the spent oil from the auto-technicians. Such re-use practices include, but not limited to, use as boiler fuel in industries, weed control, use for wood preservation against termites, rust prevention for motor spare parts, etc. Most of these practices are not environmentally-friendly.

On the awareness of hazards of spent oil, only $40 \%$ (57) said that they were aware of the environmental and health hazards of spent oil. The remaining 60\% (87) were not aware of these hazards. This finding is in agreement with Zitte et al. [8] who found that only $30 \%$ of respondents were aware of the dangers of spent oil. This lack of awareness by the majority of auto-technicians may have 
given rise to the huge environmental pollution of spent oil in our environment.

The findings on the awareness of recycling for generated spent oil, showed that $76 \%$ (109) of respondents were not aware that spent oil could be recycled. The finding agrees with that of Omorowa and Agu [7] who found 63\% and attributed it to lack of awareness.

Mean PAHs concentrations ranged from $214.83 \mathrm{mg} / \mathrm{kg}$ to $537.22 \mathrm{mg} / \mathrm{kg}$. The lowest mean concentration was obtained in Trans Amadi sample point while the highest mean concentration was obtained in Rumuodara. However, these mean values did not follow any pattern but were lower than the WHO limit for PAHs which is $1 \mathrm{mg} / \mathrm{kg}(1000 \mu \mathrm{g} / \mathrm{kg})$, as reported by Nwaichi et al. [9]. A number of polycyclic aromatic hydrocarbons are potentially toxic and carcinogenic following prolonged exposure via soil and food crops contamination. They can also cause kidney and liver diseases as reported by Nwaichi et al. [9].

\section{Conclusion}

Indiscriminate storage and disposal of spent oil, as practiced by the autotechnicians negatively impacts soil property which will in turn affect use and function. Topsoils in studied automobile workshops contained PAHs resulting majorly from the poor handling of spent oil by the auto technicians. This may have a lot of negative health implications for plants and animals, including man who deals directly or indirectly with the environment. The mean concentrations of PAHs were much higher than the set WHO standards for PAHs in soil. The study therefore recommends that Government should enact and enforce legislations for the comprehensive management of spent oil from generation, collection, storage, disposal to recycling. They should also organize awareness programmes to improve uptake of learning. This may be done in partnership with the private sector and could include the establishment of spent oil collection centres in each local government area in the country. This will enable the autotechnicians to sell their generated spent oil to state-owned or private recycling plants. This in turn will create jobs for the teeming masses of our unemployed youths, alleviate poverty and improve the quality of the environment.

\section{Conflicts of Interest}

The authors declare no conflicts of interest regarding the publication of this paper.

\section{References}

[1] NBS (2018) Nigeria Road Transport Data. Nigerian Bureau of Statistics.

[2] Bamiro, A.O. and Osibanjo, O. (2004) Pilot Study of Used Oils in Nigeria. International Journal of Mathematics and Computer Sciences, 15, 100-165.

[3] Nwachukwu, M.A., Alinmor, J. and Feng, H. (2012) Review and Assessment of Mechanic Village Potentials for Small-Scale Used Engine Oil Recycling Business. African Journal of. Environmental Science and Technology, 6, 464-475. https://doi.org/10.5897/ajest12.091 
[4] Akpakpavi, M. (2015) Used Oil Storage and Disposal Practices in Automobile Repair Garages in Ghana. International Journal of Science, Technology and Society, 3, 191-201. https://doi.org/10.11648/j.ijsts.20150304.23

[5] NPC (2006) National Population Commission. 2006 Census in Nigeria.

[6] Yamani, T. (1967) Statistics: An Introductory Analysis. 2nd Edition, Harper and Row, New York.

[7] Omorowa, F.E. and Agu, K.C. (2017) Level of Awareness and Perceptions about the Health Hazards os Spent Engine Oil on Exposed Auto-mechanics around Benin City Metropolis, Southern Nigeria. Sokoto Journal of Medical Laboratory Science, 2 , 15-27.

[8] Zitte, L.F., Awi-Waadu, G.D.B. and Okorodike, C.G. (2016) Used Oil Generation and Its Disposal along East-West Road, Port Harcourt, Nigeria. International Journal of Waste Resources, 6, 195. https://doi.org/10.4172/2252-5211.1000195

[9] Nwaichi, E.O., Chuku, L.C. and Ighoavwogan, E. (2016) Polycyclic Aromatic Hydrocarbons and Selected Heavy Metals in Some Oil Polluted Sites in Delta State, Nigeria. Journal of Environmental Protection, 7, 1389-1410.

https://doi.org/10.4236/jep.2016.710120 